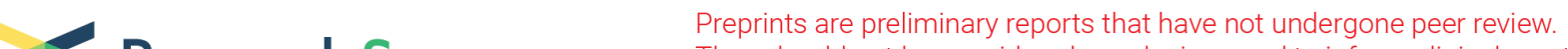 Research Square They should not be considered conclusive, used to inform clinical practice, or referenced by the media as validated information.
}

\section{Evaluation Of Filter Cake Oil As Antifoam In Yeast Production. New Use For This By-Product Of The Sugarcane Derivatives Industry}

Indira Pérez Bermúdez ( $\nabla$ indilachirri@gmail.com )

Cuban Research Institute of Sugar Cane Derivatives https://orcid.org/0000-0001-9098-3511

Arletis Cruz Llerena

Cuban Research Institute of Sugar Cane Derivatives https://orcid.org/0000-0002-8113-1592

Keyla Tortoló Cabañas

Cuban Research Institute of Sugar Cane Derivatives https://orcid.org/0000-0002-9661-9830

Manuel Díaz de los Ríos

Cuban Research Institute of Sugar Cane Derivatives https://orcid.org/0000-0003-2168-0263

Miguel Ángel Peña

Cuban Research Institute of Sugar Cane Derivatives https://orcid.org/0000-0002-6713-1510

José Vela

Cuban Research Institute of Sugar Cane Derivatives https://orcid.org/0000-0002-2897-6967

\section{Research Article}

Keywords: antifoam property, defoamer, filter cake oil, Candida yeast, Hansen solubility parameters

Posted Date: April 27th, 2021

DOI: https://doi.org/10.21203/rs.3.rs-392201/v1

License: (c) (i) This work is licensed under a Creative Commons Attribution 4.0 International License. Read Full License 


\section{Abstract}

Purpuse: Fodder yeast is obtained in an aerobic fermentation process where foaming is a major problem to be solved. In this article, the antifoam property of crude and purified filter cake oil is evaluated in order to use this residual as an alternative to replace the import of commercial antifoam agents and to reduce the production costs of fodder yeast

Method: Knock down test and the comparisons with two commercial antifoam agents were done. Blackstrap molasses medium at 20 and $40 \mathrm{~g} / \mathrm{L}$ of total reducing sugar was used. All products were studied in their pure form and commercial ones also in dilutions $1: 2$ and 1:5 v/v. Hansen's solubility parameters (HSPs) to analyze the affinity of each defoamer for yeast were determined.

Results: It was obtained the crude and purified filter cake oil showed similar behavior to commercial defoamers with an immediate antifoam effect, removing between 40 and $60 \%$ of the initial foam at both sugar concentrations in the first 5 minutes. The regression model showed purified filter cake oil has the greatest knockdown effect $(\mathrm{Ca}=55.85$ and 74.32$)$ and with greater foam suppression stability the commercial defoamer Quimifoam Máster $\left(C_{b}=-0.69\right.$ and -1.38). Ra values obtained in HSPs test, indicated the affinity of defoamers to the medium.

Conclusion: Purified filter cake oil is an effective product for its use as an antifoam with the best knock down effect for both concentrations of sugars in the medium. The determination of HSPs corroborates the effectiveness of this product to suppress foam.

\section{Statement Of Novelty}

The use of crude filter cake oil, residual from the Cuban sugarcane derivatives industry, as an antifoam was previously studied in the 90 s using it as a fatty vehicle in mixtures with esters, achieving good results. In the bibliography consulted by the authors, no recent articles are reported on its use after it has been purified. Therefore, the novelty of this work is the evaluation of the antifoam property of purified filter cake oil, which offers the possibility of a new use of this by-product with the consequent impact on the reduction of fodder yeast production cost by the replacement of commercial defoamers, products that are imported and with high prices in the market.

\section{Introduction}

In fermentation processes, foam formation is inevitable and occurs as a consequence of the introduction of large masses of air into the process and the presence of colloidal substances or long-chain organic compounds (soluble proteins, alcohols, etc.) [1]. There are different ways to control and/or remove foam, such as the use of mechanical devices, removal of foaming agents from process units that prevent their formation, spreading water over it or breaking down by applying pressured flows over foam [2]. However, the most widely used method is applying antifoam agents of different natures. 
Candida utilis fodder yeast, commonly named Torula yeast, is the most widely used microorganism in the production of unicellular protein as an established product with good acceptance in feed formulation for animal nutrition $[3,4]$. It is obtained from heavy aerobic fermentation of a sugar-rich medium where foam formation occurs, which is a major problem that must be addressed.

Generally, for foam control, a wide range of antifoam commercial products with dissimilar properties and compositions have been used, but most contain oils (silicone, mineral, fluorocarbons), solid particles (silica, calcium, plastic beds), or mixtures of the latter with amphiphilic particles and molecules (alcohols, fatty acids, fatty esters) [5]. The defoamers used in yeast production are mainly based on fatty acids, fatty acid esters and aliphatic alcohols, among others [6].

Use of some types of vegetable oils such as jojoba, sunflower, coconut oil, soybeans and rapeseed, have been reported as defoamers in different productions to replace commercial ones with good results [6-9]. Januskiewicz [10] and Montano et al. studied filter cake oil for this purpose in fermentation industry, highlighting it has a composition, similar to some other (previous) vegetable oils reported by Cevada et al. [2], Kougias et al. [7], McClure et al. [9], Soomro and Sherazi [12], Chalupud et al [13], Porto and Lopes [14], inducing a notable antifoam effect.

Filter cake oil composition, according to Montano et al. [11], Reinosa [15] and Silveira [16], is fundamentally constituted by a mixture of fatty acids such as linolenic (36.1\%), palmitic (25\%), oleic (10.2\%), linolinic (6.9\%), arachidic (7.6\%), stearic (4.6\%), myristic (3.1\%), capric (1.2\%) and caprylic (2.0\%) and variable amounts of waxy esters (between 5 and $20 \%$ ). These compounds have well-characterized defoaming properties according to the literature in this field $[7,9]$.

Filter cake oil is a by-product of sugarcane wax refining process. Its use as an antifoam agent in fodder yeast production would be of interest to sugar and derivatives industry because it offers two options: the possibility of a new use of this by-product and also it would have an impact on reduction of Torula yeast cost production by substituting commercial defoamers, products that are imported and of high prices.

In consulted bibliography by the authors, no recent reports of the use of filter cake oil as antifoam were found. In the reports of Montano et al [11, 16], antifoam effect of filter cake oil as a fatty vehicle in mixtures with different esters (monopalmitate, monomyristate, monotannate, monooleate and monostearate) was tested compared with sunflower oil. In these studies, best results were obtained when filter cake oil was used, with a similar procedure of commercial defoamers. Taking these results as a starting point, the objective of this work is to evaluate antifoam property of pure filter cake oil (without mixing with other compounds) in the production of Candida utilis yeast.

\section{Materials And Methods}

\section{Materials}


Two types of filter cake oil, one with high content of wax or crude (CACHA) (average dry base composition of $79 \%$ oil, $16 \%$ wax and $5 \%$ impurities) obtained from the sugarcane wax refining factory annexed to Majibacoa sugar mill (Las Tunas Province, Cuba) and other a purified filter cake oil (CACHAP) were tested (processed) at The Cuban Research Institute of Sugar Cane Derivatives (ICIDCA). Also two commercial defoamers: Silicone antifoam B30 (FV) (non-ionic emulsion system) (Carini Chem SRL, Italy) and Quimifoam Máster (C10) (anionic emulsion system) (Zucker S.A, México), both specially used for fermentation processes in alcohol distilleries and yeast plants, were evaluated.

Commercial defoamers were studied in their pure form and in dilutions of $1: 2$ and $1: 5$, as this is the way they are used in industry. In all cases, the behavior obtained from them was compared with filter cake oils.

\section{Methods}

\section{Defoaming Potential}

To study the defoaming potential was made a Knock down physical test, a $1000 \mathrm{~mL}$ cylinder with an air diffuser was used. Air flow was provided by a compressor (Oks Otto Klein Gmbh, Germany) and controlled by a flow meter. A stopwatch (class 0.2 seconds) was used to measure time interval in the experiments and a heating plate was employed to increase the temperature of filter cake oil when applyed to the medium.

Defoamers were studied in the laboratory to know their potential to suppress foam on a foamy medium made up of a molasses solution at 20 and $40 \mathrm{~g} / \mathrm{L}$ of total reducing sugar (TRS). These sugar concentration was chosen because it is a substrate being used in many fermentation processes, they were likely to provide a foaming system broadly representative of industrial production of Torula yeast. As indicator parameter of antifoam character was considered the effect it produces over dynamic foam. Experiments were carried out at room temperature $\left(25^{\circ} \mathrm{C}\right)$.

Procedure was done according to the method reported by Montano et al [11] and Kato et al [17]. A $500 \mathrm{~mL}$ of molasses solution was poured into the cylinder. Air flow was adjusted at $4 \mathrm{vvm}$ to promote foam formation of the medium volume.

Mollasses solutions at the concentrations used had different fluid properties and material content (sugars and impurities), so the surface tension was not the same and this caused the volume of the initial foam to be different.

When foam volume reached $600 \mathrm{~mL}$ for the solution of $20 \mathrm{~g} / \mathrm{L}$ TRS and $650 \mathrm{~mL}$ for $40 \mathrm{~g} / \mathrm{L}$, a drop of the antifoam to be evaluated (volume equivalent to $0.05 \mathrm{~g}$ ) was dropped with the aid of a micropipette. In the case of crude filter cake oil was dropped $0.5 \mathrm{ml}$. Volume of foam generated was measured every minute for a period of 15 minutes; this way a "variable of response" was obtained, as "the relative foam removal as a function of time". 
Relative foam removal (RFR) was calculated measuring foam volume at minute 0 as the initial minute (ini) and at the other time intervals ( $\mathrm{t}$ ) as shown in Eq. 1.

\section{$\operatorname{RFR}(\%)=\frac{\text { Foam volume (ini)-Foam volume }(\mathrm{t})}{\text { Foam volume }(\text { ini) }} \times 100$}

\section{Hansen Solubility Parameters Determination (HSPs)}

HSPs determination is a tool to express affinity degree between a solute and any solvent, based on the Hansen theory, which remarks "likes attracts likes". Hansen parameters of different solutes and solvents $\left(\delta_{D}, \delta_{H}, \delta_{P}\right)$ may be plotted in a three-dimensional graph plot $x, y, z$. Closer the solute-solvent pair is in a three-dimensional space, more soluble they are. Affinity of defoamers with surfactant medium (yeast) was determinated quantitatively calculating the distance $\left(R_{a}\right)$ of Hansen factors obtained for each one (Eq. 2).

$R a=\left[4\left(\delta_{d 1}-\delta_{d 2}\right)^{2}+\left(\delta_{p 1}-\delta_{p 2}\right)^{2}+\left(\delta_{h 1}-\delta_{h 2}\right)^{2}\right]^{1 / 2}$

where:

$\delta_{d}, \delta_{p}, \delta_{h}:$ Hansen factors of coordinates d, p, h

${ }^{1}$ surfactant

2 antifoam

Hansen's parameters were determined by Hansen solubility sphere method, from the affinity test with organic solvents of known HSPs. Hansen parameters of foamers studied were obtained experimentally according to a methodology described in detail by Kato et al [17] and Hernández et al [18]. Through the Yamamoto Molecule Breaking (Y-MB) methods of contribution of functional groups and a knowledge of their expression SMILE (Simplified Molecular Input Line Entry Specification), developed by Abbott and Yamamoto $\mathrm{H}$ [19] and available in HSPiP software version 5.2.0. Hansen parameters of Candida utilis yeast amino acids were determined because they were the soluble components of the medium causing the foam.

\section{Statistical Analysis}

In knock down tests each experimental condition was performed by triplicate and data were statistically analyzed in Statgraphics Centurion XVII.2 program, at time 5, 10 and 15 minutes.

One-way analysis of variance (Simple ANOVA) and the "least significant difference" (LSD) test was used to compare statistical differences between means values. Differences were considered significant at $p$ value $<0.05$. Also, to determine activity of each defoamer a regression model adjustment of relative foam 
removal as a function of time for the defoamers in pure form in each medium concentration studied was performed.

\section{Results And Discussion}

\section{Defoaming potential}

Table 1 presents foam height values for all defoamers tested in this study during the 15 minutes time of the test and Fig. 1 shows the behavior of foam removal percentage (RFR) versus time, obtained in knock down test. Four tested defoamers had an immediate effect over foam when they were added, decreasing its volume rapidly and keeping foam level controlled below the initial value throughout the test; this indicates the compounds are able in changing interfacial properties of a liquid, resulting in an extensive foam suppression. 
Table 1

Foam height (mean \pm standard deviation) vs time for all the experimental conditions studied

\begin{tabular}{|c|c|c|c|c|c|c|c|c|}
\hline \multirow{3}{*}{$\begin{array}{l}\text { Time } \\
\text { (min) }\end{array}$} & \multicolumn{8}{|c|}{ Foam height (ml) } \\
\hline & \multicolumn{4}{|c|}{$20 \mathrm{~g} / \mathrm{L}$ TSR } & \multicolumn{4}{|c|}{$40 \mathrm{~g} / \mathrm{L}$ TSR } \\
\hline & CACHA & $\mathrm{C} 10$ & FV & CACHAP & CACHA & C10 & FV & CACHAP \\
\hline 1 & $\begin{array}{l}50.0 \pm \\
0.0\end{array}$ & $\begin{array}{l}50.0 \pm \\
0.0\end{array}$ & $\begin{array}{l}50.0 \pm \\
0.0\end{array}$ & $\begin{array}{l}50.0 \pm \\
0.0\end{array}$ & $\begin{array}{l}65.0 \pm \\
21.2\end{array}$ & $\begin{array}{l}50.0 \pm \\
0.0\end{array}$ & $\begin{array}{l}50.0 \pm \\
0.0\end{array}$ & $\begin{array}{l}50.0 \pm \\
0.0\end{array}$ \\
\hline 2 & $\begin{array}{l}52.5 \pm \\
3.5\end{array}$ & $\begin{array}{l}50.0 \pm \\
0.0\end{array}$ & $\begin{array}{l}50.0 \pm \\
0.0\end{array}$ & $\begin{array}{l}50.0 \pm \\
0.0\end{array}$ & $\begin{array}{l}75.0 \pm \\
21.2\end{array}$ & $\begin{array}{l}50.0 \pm \\
0.0\end{array}$ & $\begin{array}{l}55.0 \pm \\
7.1\end{array}$ & $\begin{array}{l}50.0 \pm \\
0.0\end{array}$ \\
\hline 3 & $\begin{array}{l}52.5 \pm \\
3.5\end{array}$ & $\begin{array}{l}50.0 \pm \\
0.0\end{array}$ & $\begin{array}{l}50.0 \pm \\
0.0\end{array}$ & $\begin{array}{l}55.0 \pm \\
0.0\end{array}$ & $\begin{array}{l}80.0 \pm \\
14.1\end{array}$ & $\begin{array}{l}55.0 \pm \\
7.1\end{array}$ & $\begin{array}{l}60.0 \pm \\
0.0\end{array}$ & $\begin{array}{l}50.0 \pm \\
0.0\end{array}$ \\
\hline 4 & $\begin{array}{l}57.5 \pm \\
3.5\end{array}$ & $\begin{array}{l}50.0 \pm \\
0.0\end{array}$ & $\begin{array}{l}50.0 \pm \\
0.0\end{array}$ & $\begin{array}{l}57.5 \pm \\
0.0\end{array}$ & $\begin{array}{l}87.5 \pm \\
10.6\end{array}$ & $\begin{array}{l}55.0 \pm \\
7.1\end{array}$ & $\begin{array}{l}62.5 \pm \\
3.5\end{array}$ & $\begin{array}{l}50.0 \pm \\
0.0\end{array}$ \\
\hline 5 & $\begin{array}{l}57.5 \pm \\
3.5\end{array}$ & $\begin{array}{l}52.5 \pm \\
0.0\end{array}$ & $\begin{array}{l}52.5 \pm \\
0.0\end{array}$ & $\begin{array}{l}57.5 \pm \\
3.5\end{array}$ & $95.0 \pm 7.1$ & $\begin{array}{l}57.5 \pm \\
10.6\end{array}$ & $\begin{array}{l}65.0 \pm \\
3.5\end{array}$ & $\begin{array}{l}60.0 \pm \\
0.0\end{array}$ \\
\hline 6 & $\begin{array}{l}60.0 \pm \\
0.0\end{array}$ & $\begin{array}{l}52.5 \pm \\
3.5\end{array}$ & $\begin{array}{l}55.0 \pm \\
3.5\end{array}$ & $\begin{array}{l}62.5 \pm \\
3.5\end{array}$ & $\begin{array}{l}100.0 \pm \\
0.0\end{array}$ & $\begin{array}{l}65.0 \pm \\
7.1\end{array}$ & $\begin{array}{l}67.5 \pm \\
3.5\end{array}$ & $\begin{array}{l}65.0 \pm \\
7.1\end{array}$ \\
\hline 7 & $\begin{array}{l}65.0 \pm \\
0.0\end{array}$ & $\begin{array}{l}55.0 \pm \\
3.5\end{array}$ & $\begin{array}{l}57.5 \pm \\
0.0\end{array}$ & $\begin{array}{l}65.0 \pm \\
3.5\end{array}$ & $\begin{array}{l}100.0 \pm \\
0.0\end{array}$ & $\begin{array}{l}65.0 \pm \\
7.1\end{array}$ & $\begin{array}{l}70.0 \pm \\
0.0\end{array}$ & $\begin{array}{l}70.0 \pm \\
7.1\end{array}$ \\
\hline 8 & $\begin{array}{l}70.0 \pm \\
0.0\end{array}$ & $\begin{array}{l}57.5 \pm \\
0.0\end{array}$ & $\begin{array}{l}57.5 \pm \\
3.5\end{array}$ & $\begin{array}{l}72.5 \pm \\
7.1\end{array}$ & $\begin{array}{l}100.0 \pm \\
0.0\end{array}$ & $\begin{array}{l}65.0 \pm \\
7.1\end{array}$ & $\begin{array}{l}70.0 \pm \\
0.0\end{array}$ & $\begin{array}{l}75.0 \pm \\
7.1\end{array}$ \\
\hline 9 & $\begin{array}{l}72.5 \pm \\
3.5\end{array}$ & $\begin{array}{l}57.5 \pm \\
3.5\end{array}$ & $\begin{array}{l}60.0 \pm \\
3.5\end{array}$ & $\begin{array}{l}77.5 \pm \\
3.5\end{array}$ & $\begin{array}{l}100.0 \pm \\
0.0\end{array}$ & $\begin{array}{l}65.0 \pm \\
7.1\end{array}$ & $\begin{array}{l}72.5 \pm \\
3.5\end{array}$ & $\begin{array}{l}82.5 \pm \\
3.5\end{array}$ \\
\hline 10 & $\begin{array}{l}72.5 \pm \\
3.5\end{array}$ & $\begin{array}{l}57.5 \pm \\
3.5\end{array}$ & $\begin{array}{l}60.0 \pm \\
7.1\end{array}$ & $\begin{array}{l}82.5 \pm \\
3.5\end{array}$ & $\begin{array}{l}100.0 \pm \\
0.0\end{array}$ & $\begin{array}{l}70.0 \pm \\
7.1\end{array}$ & $\begin{array}{l}77.5 \pm \\
3.5\end{array}$ & $\begin{array}{l}87.5 \pm \\
3.5\end{array}$ \\
\hline 11 & $\begin{array}{l}75.0 \pm \\
7.1\end{array}$ & $\begin{array}{l}57.5 \pm \\
3.5\end{array}$ & $\begin{array}{l}60.0 \pm \\
7.1\end{array}$ & $\begin{array}{l}90.0 \pm \\
3.5\end{array}$ & $\begin{array}{l}100.0 \pm \\
0.0\end{array}$ & $\begin{array}{l}72.5 \pm \\
7.1\end{array}$ & $\begin{array}{l}77.5 \pm \\
3.5\end{array}$ & $\begin{array}{l}95.0 \pm \\
7.1\end{array}$ \\
\hline 12 & $\begin{array}{l}77.5 \pm \\
3.5\end{array}$ & $\begin{array}{l}57.5 \pm \\
3.5\end{array}$ & $\begin{array}{l}60.0 \pm \\
7.1\end{array}$ & $\begin{array}{l}90.0 \pm \\
0.0\end{array}$ & $\begin{array}{l}100.0 \pm \\
0.0\end{array}$ & $\begin{array}{l}75.0 \pm \\
7.1\end{array}$ & $\begin{array}{l}80.0 \pm \\
0.0\end{array}$ & $\begin{array}{l}97.5 \pm \\
3.5\end{array}$ \\
\hline 13 & $\begin{array}{l}77.5 \pm \\
3.5\end{array}$ & $\begin{array}{l}57.5 \pm \\
3.5\end{array}$ & $\begin{array}{l}60.0 \pm \\
7.1\end{array}$ & $\begin{array}{l}90.0 \pm \\
0.0\end{array}$ & $\begin{array}{l}100.0 \pm \\
0.0\end{array}$ & $\begin{array}{l}75.0 \pm \\
7.1\end{array}$ & $\begin{array}{l}80.0 \pm \\
0.0\end{array}$ & $\begin{array}{l}100 \pm \\
0.0\end{array}$ \\
\hline 14 & $\begin{array}{l}77.5 \pm \\
3.5\end{array}$ & $\begin{array}{l}57.5 \pm \\
3.5\end{array}$ & $\begin{array}{l}62.5 \pm \\
7.1\end{array}$ & $\begin{array}{l}90.0 \pm \\
0.0\end{array}$ & $\begin{array}{l}100.0 \pm \\
0.0\end{array}$ & $\begin{array}{l}75.0 \pm \\
7.1\end{array}$ & $\begin{array}{l}80.0 \pm \\
0.0\end{array}$ & $\begin{array}{l}105 \pm \\
7.1\end{array}$ \\
\hline 15 & $\begin{array}{l}77.5 \pm \\
3.5\end{array}$ & $\begin{array}{l}57.5 \pm \\
3.5\end{array}$ & $\begin{array}{l}62.5 \pm \\
3.5\end{array}$ & $\begin{array}{l}90.0 \pm \\
0.0\end{array}$ & $\begin{array}{l}100.0 \pm \\
0.0\end{array}$ & $\begin{array}{l}78.0 \pm \\
2.8\end{array}$ & $\begin{array}{l}82.5 \pm \\
3.5\end{array}$ & $\begin{array}{l}105 \pm \\
7.1\end{array}$ \\
\hline
\end{tabular}


In the first 5 minutes, it was possible to remove between 40 and $60 \%$ of the initial foam at both concentrations (20 and $40 \mathrm{~g} / \mathrm{L}$ of TSR), although higher values were sometimes reached for the latter concentration. These results have coincide with the proposed by McClure et al [9], who suggested compounds present in molasses can "displace" the defoamer of the interface, implying a decrease in its effect after a given period of time and also indicates a need to add another defoamer dose.

For a concentration of $20 \mathrm{~g} / \mathrm{L} \mathrm{TSR}$ (Fig. 2A), it was observed that from the two commercial defoamers (FV and $\mathrm{C} 10) \mathrm{C} 10$ has highest stability of foam removal. Removal capacity of non-commercial defoamers (CACHA and CACHAP) compared to commercial ones - at 5 minutes of its addition to the system - was similar, because no significant differences were detected with a P-value $(0.3813)$ greater than 0.05 , with a $95 \%$ confidence level. After 10 minutes, commercial defoamers had a more stable effect on foam control and CACHA shows better results than CACHAP.

After 10 and 15 minutes of analysis at both total sugar concentrations in the medium ( 20 and $40 \mathrm{~g} / \mathrm{L}$ ), differences were detected between commercial and non-commercial defoamers with values lower than 0.05 (0.0173 and 0.0014 respectively), with 95\% confidence. Commercial defoamers FV and C10 had a similar behavior throughout the analysis without showing significant differences between them in "foam removal percentage"(RFR). Figure 2A shows in comparison between commercial defoamers and noncommercial defoamers, after 10 minutes of starting the test, foam removal percentage is completely differently significant, since FV and C10 continued removing around $20 \%$ more than the non-commercial ones. For CACHA and CACHAP defoamers, significant differences were only detected between them at 15 minutes of addition when they reached values of 22.5 and $10 \%$ of foam removal respectively. These results show, at $20 \mathrm{~g} / \mathrm{L}$ TSR concentration for 15 minutes, CACHA can be considered a better option than CACHAP. During the test, the removal values of all the defoamers evaluated were around $50 \%$, which is considered a value below the expected result.

At a concentration of $40 \mathrm{~g} / \mathrm{L}$ TSR (Fig. 2B), purified filter cake oil (CACHAP) exhibits a foam removal behavior similar to commercial defoamers and superior to crude oil (CACHA). The behavior of the commercial defoamers (FV and C10) at this concentration was similar to that obtained for a concentration of $20 \mathrm{~g} / \mathrm{L}$ TSR where $\mathrm{C} 10$ had the greatest influence on the stability of the foam.

In general, among non-commercial defoamers, the most unfavorable behavior corresponds to CACHA with the lowest foam removal at all times evaluated with significant differences, with $P$ values $(0.0131$, $0.0079,0.0059$ ) less than 0.05 for 5,10 and 15 minutes respectively, with $95 \%$ confidence. CACHAP presented similar values to commercial defoamers after 5 minutes of their addition, detecting significant differences only after 15 minutes, time in which their behavior is similar to that obtained for CACHA.

The behavior of the commercial defoamers diluted 1:2 and 1: 5 was compared with the non-commercial ones in their pure form under the same working conditions. For the concentration of $20 \mathrm{~g} / \mathrm{L}$ TRS in the medium at a 1: 2 dilution (Fig. 3A), significant differences were found when comparing commercials with CACHA and CACHAP at 10 and 15 minutes, with a confidence level of $95 \%$ and $P$ values less than 0.05 ( 0.013 and 0.0096 respectively). Greater instability was observed for commercial defoamers when 
working with a 1: 5 dilution as shown in Fig. 3B, mainly for $\mathrm{C} 10$, which, after 15 minutes, could no longer remove the foam from the system.

Figure 4 represents the same behavior, but for concentrations of $40 \mathrm{~g} / \mathrm{L}$ TSR. Significant differences were detected between commercial defoamers, especially for the more dilute condition (Fig. 4B). CACHAP showed a favorable response, with better foam removal behavior and higher values than diluted commercial defoamers and CACHA.

\section{Regression model analysis}

Taking into consideration what was proposed by Montano et al [11], to determine the antifoam with the best knock down effect and the highest stability of foam removal, a linear regression model was adjusted. Adjustment was made for pure defoamers and at both concentrations of TRS in the medium. Antifoam activity was characterized by the values of intercept $(\mathrm{Ca})$ and the slope $(\mathrm{Cb})$ of the adjusted model.

In regression equation obtained (Eq. 3), intercept indicates antifoam ability of rapidly depress of foam (knock-down) while the slope is related to the duration or stability of this effect. This way, best results are associated with the highest values for $\mathrm{Ca}$ and $\mathrm{Cb}$.

\section{Relative foam remotion $=\mathrm{C}_{\mathrm{a}}+\mathrm{C}_{\mathrm{b}} \times$ time}

Figure 1 shows the results of the adjusted model, with their respective values of $C_{a}, C_{b}$ and the correlation coefficient $R^{2}$. From the results obtained with model adjustment, it can be stated that for $20 \mathrm{~g} / \mathrm{L}$ TSR (Fig. 5A), defoamer with best knock-down effect $\left(\mathrm{C}_{\mathrm{a}}\right)$ was CACHAP, since it got highest intercept value. When comparing values obtained, it was observed better results were achieved by commercial defoamers compared to non-commercial ones (CACHA and CACHAP). However, results of Simple ANOVA analysis did not detect significant differences between defoamers evaluated with a $P$ value greater than 0.05 (0.527) with $95 \%$ confidence, indicating any of them can be employed.

In addition, analyzing $\mathrm{C}_{\mathrm{b}}$ value of "foam suppression stability" determination, results indicate $\mathrm{C} 10$ was more favorable because it shows highest slope and a p value less than 0.05 (0.0106) was obtained, indicating presence of significant differences of this parameter, with a $95 \%$ confidence. When multiple range test was applied with Fisher's "least significant difference (LSD) procedure", differences were detected between this defoamer and the non-commercial ones (CACHA and CACHAP), which had no differences between them; so suppressive effect of the latter is similar.

In case of $40 \mathrm{~g} / \mathrm{L}$ TSR if the highest value of the slope calculated, when regression equation is considered, the one with greatest stability was crude filter cake oil (CACHA), however considering the low correlation coefficient $\mathrm{R}^{2}$, it was discarded, since result only explained $62 \%$ of its behavior as antifoam. Therefore, the one with highest stability $\left(C_{b}\right)$ was $C 10$. Regarding knock-down effect $\left(C_{a}\right)$, best result was achieved with CACHAP. At this concentration, results of ANOVA analysis did not detect significant 
differences with $C_{b}$ but significant differences for $C_{a}$, with $P$ values of ( 0.0435 and 0.0627 respectively) and a $95 \%$ confidence level; differences of $C_{b}$ were established between CACHA and the rest of evaluated defoamers.

Based on the results obtained, the purified filter cake oil can be used successfully as an antifoam in this medium. Its application in raw form is not recommended since its effect in suppressing the foam was inferior. In addition, due to its high wax content, it can cause incrustations in the equipment and its application to the environment is difficult, since because it is very dense (pasty) it must be added at a temperature close to $60^{\circ} \mathrm{C}$.

Filter cake oil is a by-product of the sugarcane industry, which is available and its use as a defoamer can be an interesting and economical option for the production of Candida utilis; since it will allow the substitution of commercial defoamers that have a high cost in the market.

\section{Hansen Solubility Parameters (HSPs)}

A medium where these defoamer should be used is a mixtures of different compounds and where yeast has a concentration of $10 \mathrm{~g} / \mathrm{l}$. For Hansen solubility parameters calculation of the medium, the amino acids that characterize Candida utilis yeast were taken as a reference and coincide with those present in either molasses or vinasse, which are the carbon sources normally used as a culture medium in this process; amino acid composition for Candida utilis yeast reported by Yañez [20] y Otero and Almazán [21] was assumed. From mass percent and densities of each amino acid, the volumetric percent were obtained by calculating mixture density by trial and error. HSPs of the mixture were calculated from the sum of Hansen's parameters of each amino acid, affected by the volumetric contribution of each one to the medium. Table 2 shows the amino acids present in the medium and their respective HSPs. 
Table 2

Hansen solubility parameters of amino acids in the medium

\begin{tabular}{|c|c|c|c|c|c|}
\hline Amino acids & $\delta_{d}(\mathrm{MPa})^{1 / 2}$ & $\delta_{\mathrm{p}}(\mathrm{MPa})^{1 / 2}$ & $\delta_{h}(\mathrm{MPa})^{1 / 2}$ & $\%(w / w)$ & $\%(v / v)$ \\
\hline Leucine & 16.2 & 5.3 & 12.0 & 9.28 & 10.86 \\
\hline Valine & 16.3 & 5.9 & 13.1 & 8.36 & 9.51 \\
\hline Lysine & 17.2 & 7 & 14.1 & 8.89 & 9.44 \\
\hline Isoleucine & 16.3 & 5 & 11.7 & 7.03 & 8.21 \\
\hline Arginine & 17.7 & 9.2 & 15.5 & 7.16 & 6.81 \\
\hline Threonine & 17.3 & 9.3 & 21.0 & 7.29 & 6.80 \\
\hline Serine & 17.7 & 10.8 & 23.0 & 7.29 & 6.29 \\
\hline Glycine & 18 & 9.3 & 19.6 & 6.37 & 6.14 \\
\hline Phenylalanine & 18.3 & 5.5 & 11.8 & 5.70 & 5.71 \\
\hline Glutamic acid & 17.7 & 9.5 & 20.7 & 6.23 & 5.51 \\
\hline Aspartic acid & 18.1 & 9.4 & 21.6 & 6.23 & 5.17 \\
\hline Proline & 17.7 & 7.7 & 13.2 & 4.64 & 4.75 \\
\hline Alanine & 17.1 & 7.7 & 17 & 4.51 & 4.72 \\
\hline Tyrosine & 19.2 & 7.8 & 16.7 & 4.38 & 4.06 \\
\hline Histidine & 19.4 & 12.1 & 16.7 & 2.52 & 2.26 \\
\hline Methionine & 18.1 & 7.2 & 13.2 & 1.59 & 1.56 \\
\hline Tryptophan & 19.7 & 8.2 & 12.8 & 1.59 & 1.48 \\
\hline Cystine & 18.9 & 10.7 & 17.4 & 0.93 & 0.73 \\
\hline
\end{tabular}

HSPs obtained for defoamers studied and the Ra distance as a function of the HSPs of the medium calculated from equation 1 are tabulated in Table 3. Results obtained from Ra values for commercial defoamers are the lowest since their Hansen parameters have similar values. In the case of purified filter cake oil, this value increases because there is a greater difference in polar component, an expected behavior since commercial defoamers studied are designed for its use in this type of fermentation. Low Ra values indicate a high affinity of defoamers to the medium, which complements results obtained in physical tests. About it, C10 has highest affinity with a Ra value of 4.37 . 
Table 3

Hansen solubility parameters and distance Ra determinated in relation to the HSPs obtained for the medium

\begin{tabular}{|lllll|}
\hline Medium & $\delta_{\mathrm{d}}(\mathrm{MPa})^{\mathbf{1 / 2}}$ & $\delta_{\mathrm{p}}(\mathrm{MPa})^{\mathbf{1 / 2}}$ & $\delta_{\mathrm{h}}(\mathrm{MPa})^{\mathbf{1 / 2}}$ & $\mathrm{Ra}(\mathrm{MPa})^{\mathbf{1 / 2}}$ \\
\hline Candida utilis yeast & 17.40 & 7.67 & 15.91 & - \\
\hline Defoamer & & & & \\
C10 & 15.43 & 6.88 & 14.21 & 4.37 \\
\hline FV & 15.4 & 6.78 & 14.17 & 4.46 \\
CACHAP & 16,24 & 3,21 & 10,34 & 7.51 \\
\hline$\delta_{\mathrm{d}}, \delta_{\mathrm{p}}, \delta_{\mathrm{h}}$ Hansen solubility parameter Ra: distance between HSPs & \\
\hline
\end{tabular}

Important is to clarify Hansen parameters were not obtained for crude filter cake oil because it has a high wax content and a variable concentration, so it is expected these factors ( $\delta d, \delta p$, $\delta$ ) will be less than those of purified oil, therefore Ra will be higher and its affinity lower to the medium.

Figure 5 shows relationship between foam volume and Ra values of 5,10 and 15 min test time. In this case, it coincides with one with lowest value of Ra. C10 was the defoamer that maintains lowest foam volume, which also complements the criterion that the lower the value of $\mathrm{Ra}$, the greater the affinity with the medium. This aspect corroborates Kato et al [21] proposition where they state "use of the Ra calculation could be another criterion for selection of best antifoam". Another aspect corroborated in this test is existing similarity in foam suppressing behavior between defoamers studied and use of purified filter cake oil, meaning it may be an option to consider for its use in SCP technology.

\section{Conclusions}

The purified filter cake oil was determined to be an effective product for use as antifoam. From the analysis carried out, it was obtained that this oil presented the highest knock down effect and $\mathrm{C} 10$ presented the highest stability in foam suppression for both concentrations of TRS evaluated (20 and 40 $\mathrm{g} / \mathrm{L}$ ), although the foam removal varies depending on of the sugar concentration of the medium. The determination of the Hansen solubility parameters (HSP) and the distance between them (Ra) corroborates the effectiveness of the use of this by-product of the sugar industry to suppress the foam in the studied medium.

\section{Declarations}

\section{Acknowledgements}

The authors gratefully acknowledge to Professor Gustavo Saura Laria for his technical assistance.

\section{Funding}


Not applicable

\section{Conflicts of interest}

The authors declare no conflict of interest.

\section{Availability of data and material (data transparency)}

The data used in the article is available if required

Code availability (software application or custom code)

HSPiP software version 5.2.0

\section{Authors' contributions}

Not applicable

\section{Ethics approval}

Not applicable

\section{Consent to participate}

The authors give their consent to participate

Consent for publication (include appropriate statements)

The authors give their consent for the publication of the article

\section{References}

1. Nielsen, J.C., De Oliveira, F.S., Gundelund, T., Thykær, J., Workman, C.T., Olitta, T.: Industrial antifoam agents impair ethanol fermentation and induce stress responses in yeast cells. Appl Microbiol Biotechnol 101, 8237-8248 (2017). https://doi.org/10.1007/s00253-017-8548-2

2. Cevada, E., Roos, K., Álvarez, F., Carlotti, S., Vázquez, F.: High molar mass polyethers as defoamers of heavy crude oil. Fuel 221, 447-454 (2018). https://doi.org/10.1016/j.fuel.2018.02.136

3. Saura, G., Otero, M.A., Martínez, J.A., Fundora, N., Reyes, E., Vasallo, M.C., Almazán, O.: Propagation of yeast biomass from distillery wastes. Process and product evaluation. Int Sugar J 105, 36-39 (2003)

4. García, R., Izquierdo, Y., Ribas, M., Tortoló, K., Ibañez, M., León, O., Saura, M., Saura, G.: Effects of urea supplementation on Candida utilis biomass production from destillery waste. Waste biomass valorization 5, 119-124 (2014). https// doi.org/ 10.1007/s12649-013-9209-z 
5. Denkov, N.D., Marinova, K.G., Tcholakova, S.S.: Mechanistic understanding of the modes of action of foam control agents. Advances in Colloid and Interface Science (2013). https://doi.org/1016/j.cis.2013.08.004

6. Gélinas, P.: Aeration and Foam Control in Baker's Yeast Production: Mapping Patents. Compr Rev Food Sci Food Saf 15, 371-391 (2016). https://doi.org/ 10.1111/1541-4337.12188

7. Kougias, P.G., Tsapekos, P., Boe, K., Angelidaki, I.: Antifoaming effect of chemical compounds in manure biogas reactors. Water Res 47 (16), 6280-6288 (2013). http://dx.doi.org/10.1016/j.ces.2016.11.033

8. Cevada, E., Flores, C.A., López, A., Álvarez, F., Vázquez, F.: Study of the thermal stability of jojoba oil used as antifoaming agent in petroleum industry. J Therm Anal Calorim. (2016). http://dx.doi.org/10.1007/s10973-016-5911-y

9. McClure, D.D., Lamy, M., Black, L., Kavanagh, J., Barton, G.W.: An experimental investigation into the behaviour of antifoaming agents. Chem Eng Sci 160, 269-274 (2017). http://dx.doi.org/10.1016/j.ces.2016.11.033

10. Januskiewicz, O., Zayas, O., García, A., Redondo, D.: Concentrado de Fitosteroles a partir de Cera de Cachaza. II Int. Cong. Sugar Cane By prod. Havana. (1990)

11. Montano, R., Díaz de Arce, C., García, C.: Efecto antiespumante comparativo de esteres de girasol y cachaza respectivamente. ICIDCA Sobre deriv. caña azúcar 3, 52-59 (1993)

12. Soomro, R.K., Sherazi. S.T.H.: Extraction and characterization of seed oil waxes by using chromatographic techniques. Int. J. Ind. Chem 4, 1-7 (2013)

13. Chalapud, M.C., Ba€umler, E.R., Carelli, A.A.: Characterization of waxes and residual oil recovered from sunflower oil winterization waste. Eur. J. Lipid Sci. Technol 118, (2016). https://doi.org/10.1002/ejlt.201500608.

14. Porto, T., Lopes, R.: Designing biotechnological processes to reduce emulsions formation and improve oil recovery: study of antifoams application. Biochemical Engineering Journal (2020). https://doi.org/10.1016/j.bej.2020.107745

15. Reinosa, O.: El aceite de cera de cachaza de la caña de azúcar como fuente de sustancias naturales o precursoras de ellas. CENIC. Ciencias Químicas 35 (1), 29-31 (2004)

16. R., Díaz de Arce, C., Rodríguez, F., Montes de Oca, M., García, C., Peña, M.A.: Tarea técnica para la producción y uso del antiespumante AE-0492 para fábricas de levadura Torula de tecnología francesa y destilerías de alcohol. Subdirección de Investigaciones, ICIDCA, p 26 (1995)

17. Kato, Y., Osawa, T., Yoshihara, M., Fujii, H., Tsutsumi, S., Yamamoto, H.: Evaluation of the Antifoaming Effect Using Hansen Solubility Parameters. ACS Omega 5, 5684-5690 (2020). https://dx.doi.org/10.1021/acsomega.9b03567

18. Hernández, E., Díaz, M.; Pérez, K.: Determination of Hansen solubility parameters for sugar cane oil. Use of ethanol in sugarcane wax refining. Grasas aceites 72 (2), e 408. (2020) https:/doi.org/10.3989/gya.0326201 (impress).

19. Abbott, S., Yamamoto, H.: Software HSPiP 5.2.05. 5th Edition (2015) 
20. Yañez, E., Ballester, D., Fernández, N., Gatths, V., Monckeberg, F.: Chemical Composition of Candida utilis and the Biological Quality of the Yeast Protein. J. Sci. Fd Agric 23, 581-586 (1972)

21. Otero, M.A.; Almazán, O.: Las levaduras como base de una industria. Diferentes aplicaciones. Editorial Académica Española. Alemania (2012)

\section{Figures}
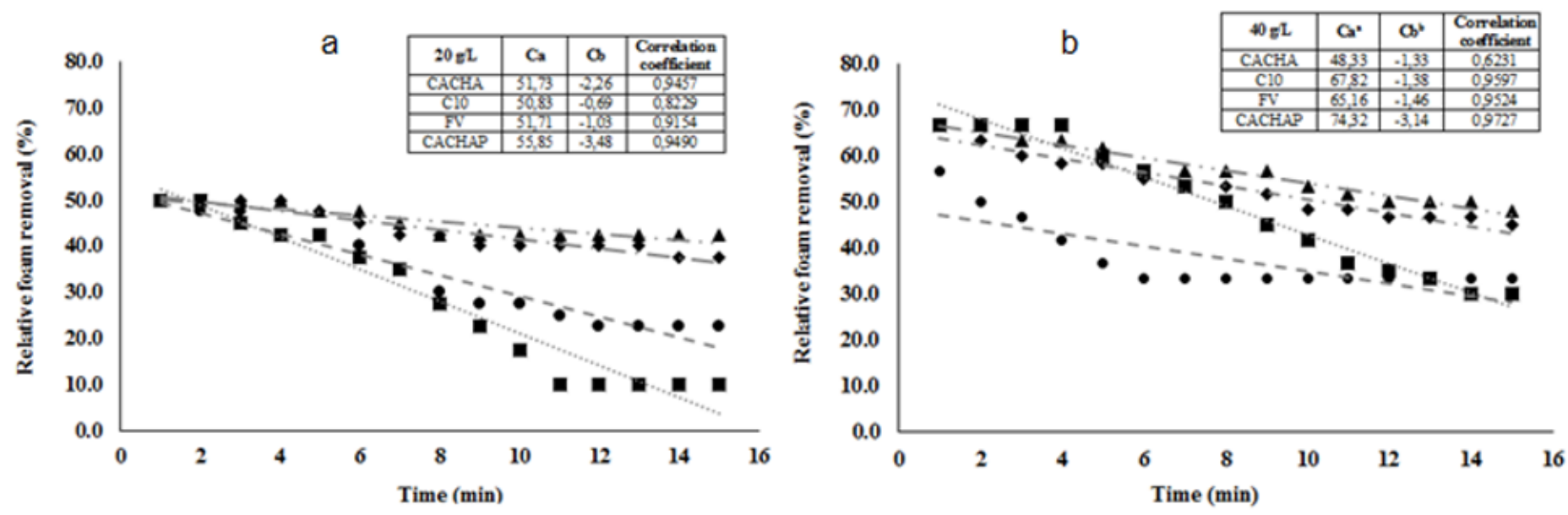

Figure 1

Behavior trend of the foam removal percentage for pure defoamers. [Please See the Manuscript File for the complete figure caption].
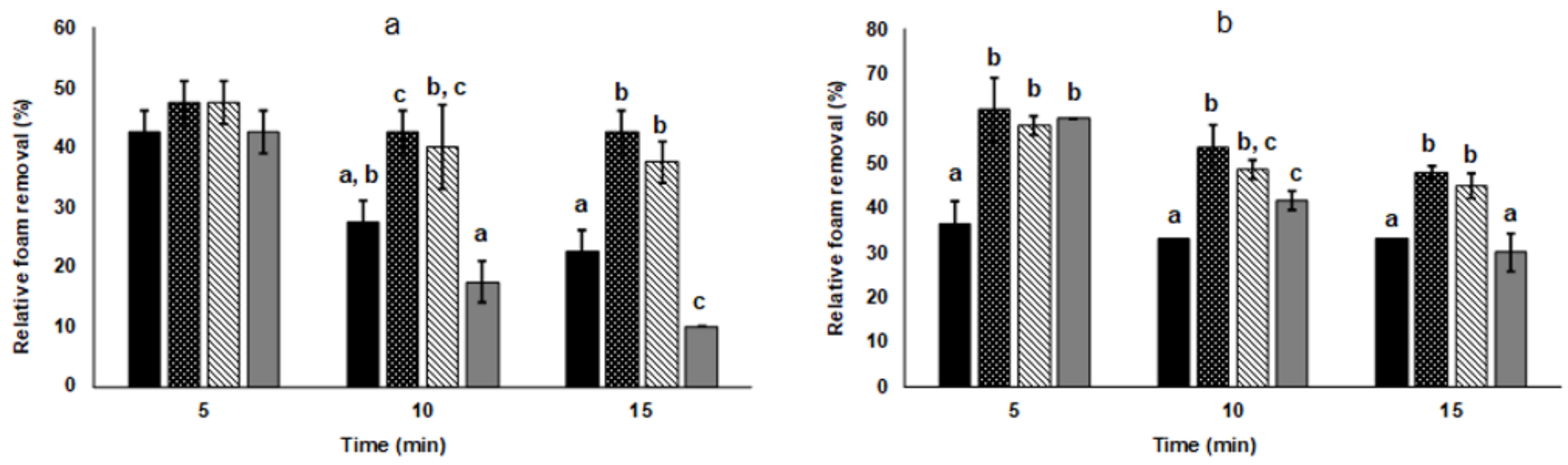

Figure 2

Capacity of foam removal of the defoamers studied vs time. [Please See the Manuscript File for the complete figure caption.] 

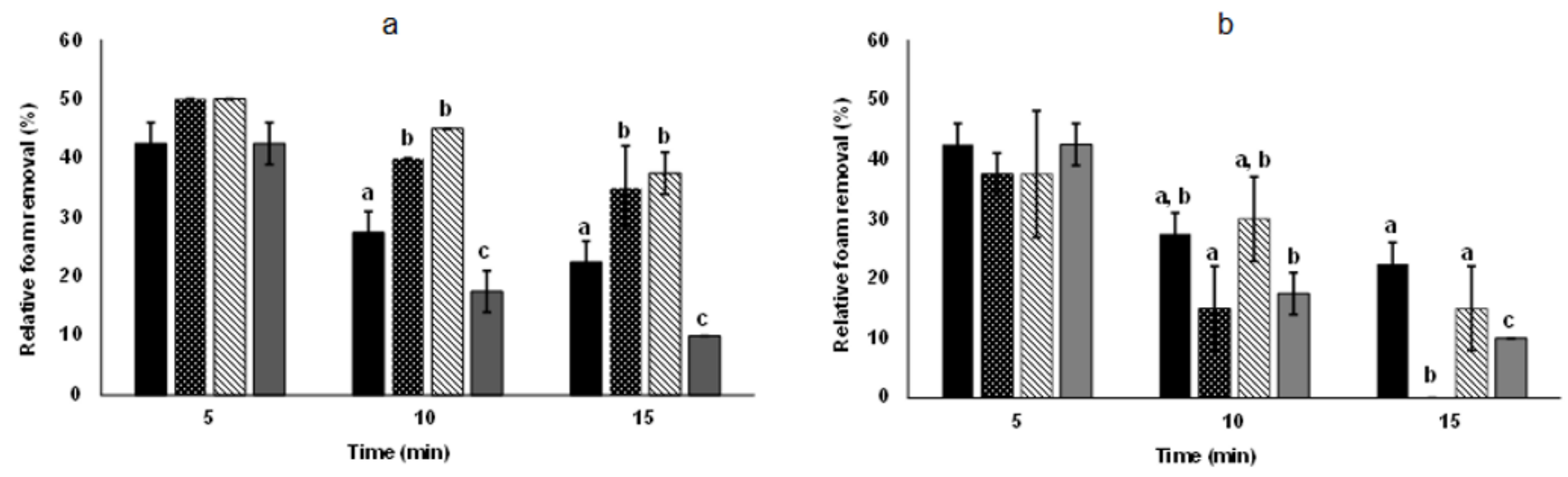

Figure 3

Comparation of filter cake oil with the commercial defoamers (dilution 1:2 and 1:5) at $20 \mathrm{~g} / \mathrm{l} \mathrm{TSR}$ in the Knock-Down test. [Please See the Manuscript File for the complete figure caption.]
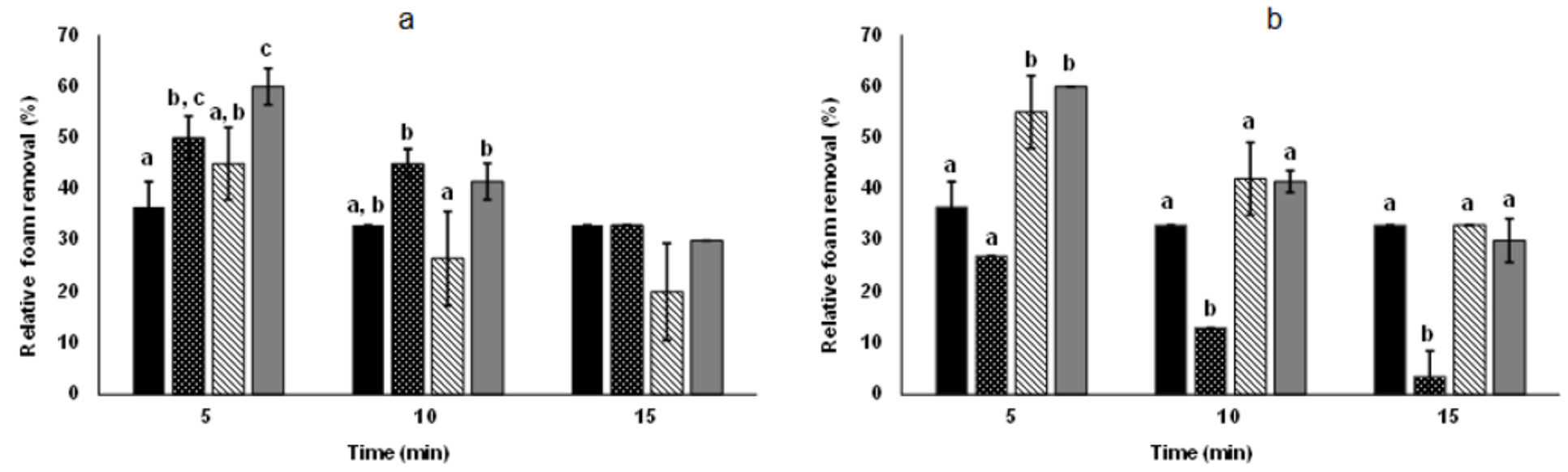

Figure 4

Comparation of filter cake oil with the commercial defoamers (dilution $1: 2$ and 1:5) at $40 \mathrm{~g} / \mathrm{l}$ TSR in the Knock-Down test. [Please See the Manuscript File for the complete figure caption.]

a

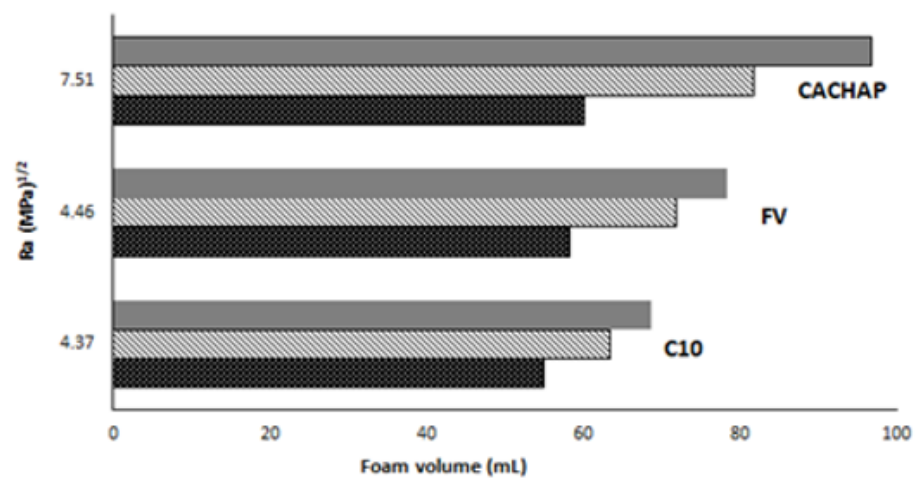

b

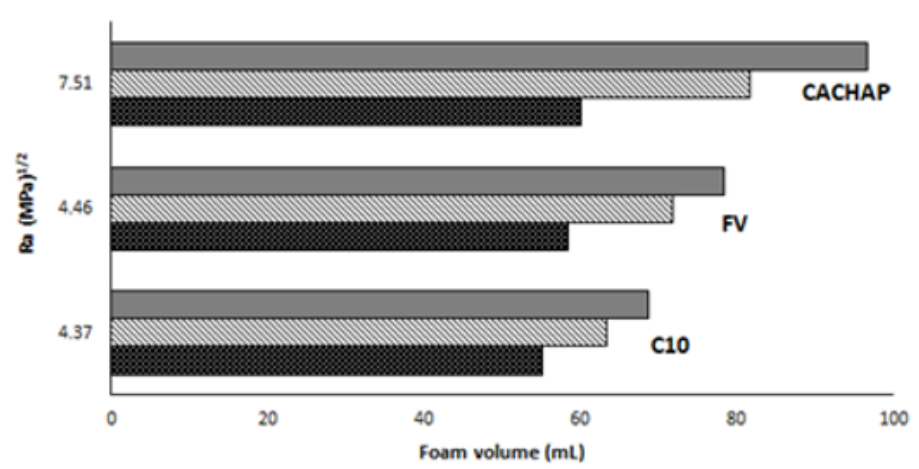

Figure 5 
Relationship between distance Ra and Foam volume. [Please See the Manuscript File for the complete figure caption.]

\section{Supplementary Files}

This is a list of supplementary files associated with this preprint. Click to download.

- GraphicAbstract.png 